\title{
Appropriation and Configuration
}

Appropriation, the process of "making (media) products one's own," is a much-discussed topic in media and cultural studies. By integrating a film into our everyday lived reality, ${ }^{2}$ we situate its "content" at a sociocultural level. It might seem that the film's audiovisual form and aesthetics are stripped away in this process and play no decisive role in its appropriation. However, in the case of historical films that would oversimplify certain deeper connections describable in the terms of film and historical theory. This chapter will therefore seek to demonstrate that the process of appropriation also irrevocably inscribes the aesthetic parameters of a cinematichistorical way of thinking into our historical consciousness.

According to Hermann Kappelhoff, appropriation of audiovisual moving images in the act of reception changes the "a priori conditions of understanding, judging, and acting." 3 This adds a refigurative component to Walter Benjamin's hypothesis that film is the "paradigm of modern perception." 4 The figurative potential to represent a simulated historical reality that is interwoven into a histosphere's audiovisual design ${ }^{5}$ can thus already be sensuously disclosed and furnished with historical meaning at a prereflective, corporal stage of reception. Building on theories of the phenomenological relationship between the spectator's body and the world, the first section of this chapter develops a model of incorporative appropriation of history, which I connect to constructivist and cognitive approaches. In the second section, I raise the specific experience of historical films described in the previous section to the status of paradigmatic

(C) The Author(s) 2021

183

R. Greiner, Cinematic Histospheres, https://doi.org/10.1007/978-3-030-70590-9_8 
core of a historical film genre, which I flesh out based on a phenomenological conception of genre. My systematic account of this genre integrates the theoretical discussion of the distinctive characteristics of historical films from the preceding chapters.

\section{INCORPORATIVE APPROPRIATION}

Films are part of a changing cultural and media system. This means that the appropriation of historical films based on physically experienced histospheres cannot be viewed in isolation from the overall media context, especially the far-reaching effects of digitalization. The ever-growing ubiquity of media technology in day-to-day life is having a profound impact on our lifeworld. ${ }^{6}$ We are almost constantly exposed to the vast information flow of the "technosphere" ${ }^{7}$ that surrounds us. This affects our understanding of history too. Live reporting on digital television, real-time news websites, and video platforms such as YouTube that are updated with new content every single second make spectators of historical events into participants in historical dramas. ${ }^{8}$ Luke Tredinnick argues that progress in media and communication technology has collapsed the distinction between the present and "the truly historical." Instead, events such as $9 / 11$ are "already historicized at the very moment that we experience them." 10 The ensuing virtuality of historical referents supports Jean Baudrillard's theory of a historical myth: Our conceptions of the past and hyperreal media reality can no longer be disentangled. ${ }^{11}$ On this view, history is a remediatization of events that have already been historicized in previous media representations. Since the resulting conceptions of history, just like cinematic histospheres, rest on audiovisual figurations, it can be assumed that the mediatization of the everyday further strengthens our capacity to intuitively experience the historical worlds simulated by historical films. The perceptual similarity between medially historicized present events and historical films can also be explained by reference to the associated processes of memory. Perceiving a constructed media reality that is conveyed as historically significant gives rise to prosthetic memories ${ }^{12}$ personal, embodied memories of the underlying historical events. When they appropriate filmic histospheres' "operational scenarios of history,"13 spectators are able to remember these experiences, so that they merge with the film's simulated historical worlds to produce a form of prosthetic postmemory. ${ }^{14}$ Consequently, appropriation of the historical worlds 
constructed by a film is always also linked to media experiences external to the film.

A further epistemological condition for analyzing fiction films' appropriation of history is that Siegfried Kracauer's and Benjamin's historical positions should be interpreted not just in terms of media theory, but also as aesthetic theories. Bernhard Groß notes that it was "optical media" that "initially made it possible to 'experience' the historical processes of the twentieth century at all." 15 Instead of "reproducing a previous reality," photography and film "were the first to structure access to this reality, which is deemed inaccessible, incomprehensible, and indecipherable."16 Historical processes became film experience "entirely as if [they] were expressing Kracauer's paradigm of historical realism or Benjamin's 'optical subconscious." "17 This implies that historical films use their specific "aids"18 to disclose "physical reality," 19 making it possible both to appropriate historical knowledge and develop conceptions of history. The interpenetration of spectator and film results, however, "not in continuity, but in a loose agglomeration of available 'knowledge." "20 According to Heike Klippel, this "fusing of disparate elements" is grounded in our perception, which interprets neither the object nor itself, but instead creates "something new." ${ }^{21}$ Consequently, the appropriation of historical films does not yield traditional, narratively structured conceptions of history, but rather a new, specifically filmic concept of history that includes the category of sensuous experience. ${ }^{22}$

In order to better understand the appropriation of history via sensuous experience of filmic histospheres, we also need to consider the phenomenological relation between the spectator's body and the world. The philosopher Alphonso Lingis has analyzed the interaction between bodily perception and empathy. ${ }^{23}$ Proceeding from an imaginary perspective shift, Lingis infers the existence of a mental body-image that places us in relation to the world. ${ }^{24}$ Through this process of incorporation, the world around us is integrated into the inner sphere of our self. ${ }^{25}$ The same process is at work in Benjamin's account of the "distracted mass" that is not absorbed by the film but, rather, absorbs it. ${ }^{26}$ In the appropriation of historical films, a histosphere's simulated historical world consequently occupies the role of an external sphere that in the process of reception becomes part of our own inner sphere. Although we know that our body is invisible to the film, we involuntarily place it in relation to the objects and subjects of the filmic world, which we as it were absorb into ourselves. Kracauer understands this form of appropriation as a sort of "blood transfusion" 
that allows us to grasp the being and dynamics of the object of our experience "from within." 27 Accordingly, in historical films we become able to physically experience the materiality of the simulated historical world by sensuously incorporating the underlying audiovisual figurations, thereby opening up new horizons of understanding. Individual experience blends with collective conceptions of history; in Landsberg's terms, historical memory becomes a portable and nonessentialist good that blurs the boundaries between personal and collective memory. ${ }^{28}$ Thus, an individual understanding of history develops not just through the externalization of memory, which migrates into film, but also through its embodied reappropriation in the process of film experience.

Furthermore, the incorporative appropriation of filmically constructed representations of history brings about a specific form of reflection, which begins with a very literal inner "mirroring" of historical worlds. Kracauer's analogy between the cinema screen and Athena's polished shield, a mirror that makes it possible to behold horrors without turning to stone, ${ }^{29}$ can be expanded to myriad historical processes, events, and narratives. In combination with mise-en-histoire, the intuitive, sensuous perception of filmic figurations enables a specific mode of access to historiographical narratives and helps produce conceptions of history. Historical films thus make it possible not just to experience historical worlds, but also to reflect on them. Histospheres' reflective potential is already inherent in the phenomenological concept of the film's embodied perspective on the historical world and the spectator's perspective on this perspective, which "appears before our eyes as perceived perception." 30 "In the movie theater," Thomas Morsch summarizes, "we don't just see something, we also see what is seen as an expression of an act of seeing." 31 This implicitly comparative schema extends into the interrelationship between film and history, though without any simplistic rhetoric of right and wrong. The traditional debate about factually accurate and realistic representations of history cleaves to a way of thinking that still takes a film's ontology to be a reproduction of reality and denies film perception the status of real experience. However, a phenomenological approach to film shows that film experience-produced by synesthetically operating audiovisual stimuli-is just as real as any other experience. A histosphere produces real historical experiences that, as Kracauer puts it, challenge us "to confront the real-life events [a film] shows with the ideas we commonly entertain about them." 32 When we reflect on the historical world with which we have had a living encounter through film, we refigure and evaluate not just the 
interpretations of history resulting from our experience of the film, but also the conceptions of history we had formed prior to watching it. Our historical consciousness, already shaped by audiovisual media, is updated and checked for any contradictions. If I previously knew the 1950s in West Germany as the era of the Wirtschaftswunder, in KU'DAMM 56 I have now also encountered it as a reactionary, patriarchal system whose demands almost drive a young woman to suicide. If my horizons were previously limited to West German history, in SKY WITHOUT STARS they are expanded to include the painful chapter of Germany's division. If until now I had only viewed the 1950s in terms of a large-scale history of events, in YEARS OF HUNGER I experience history from the perspective of an ordinary German family. Incorporative appropriation of such experiences conveys a sense of what historical lifeworlds were like. It fills the empty space between model-like filmic figurations and the historical references of the mise-enhistoire with a materiality that lends histospheres a living, multilayered structure. The embodied and prereflective dimensions of filmic experience of history are thereby combined with interpretative approaches, so that the historical experience produced by film experience can in turn become historical knowledge. ${ }^{33}$ If historical experience is understood as an "experience of difference $[\ldots]$ between one's own and the other time," 34 then this difference between times undergoes a process of interpretation "when it is integrated into an overarching conception of the passage of time that determines the cultural orientation of human ways of life." 35 This interpretive process is already inherent in the referentialization of the mise-enhistoire, and is extended by the spectator's cognitive appropriation. This can express affirmation, but can also articulate a critical or subversive potential, or even construct a counterhistory. Immersive experiences, imaginative empathy, and reminiscence triggers create a sense of physical familiarity with the film's audiovisually modeled historical worlds. This familiarity is taken up by incorporative appropriation and, in conjunction with cognitive appropriation, expanded into interpretations of history with powerful effect. ${ }^{36}$

\section{Genre Configurations}

Fiction films' audiovisual modeling of historical worlds generally draws on a repertoire of conventionalized forms. Iterative strategies for constructing historical spaces and worlds allow us to intuitively experience these spaces and worlds, and imaginatively move around them. Crane and 
sequence shots, for instance, can give us the impression of physically diving into the past world simulated by the film, serving both to show the otherness of the historical cosmos and to give us an initial sense of our bearings in time and space. Filmic figurations are also arranged and interrelated in a particular way. As Paul Ricœur would put it, they form a specific "configuration," 37 and with it histospheres' audiovisual repertoire. On the basis of immersion, empathetic engagement, imaginary referentialization, and reminiscence triggers, an impression of familiar otherness is created. If genres are a "formal organizational principle with a pool of iterative patterns, $" 38$ then histospheres can be considered the core of a historical film genre.

Film genres are typically defined as "constructs" or "symptoms of cultural processes, practices, and discourses of textual/media appropriation" 39 that are not "objective" groupings but rather "complex negotiating machines" 40 or "arenas for negotiation." 41 As an "open-textured" 42 concept, genres have diffuse boundaries, and are able to enter into hybrid constellations and change dynamically. By "reflecting on and discursifying" the "existing sociocultural practices" 43 out of which they emerge, they develop their own historicity. The "active awareness of genre" based on this process allows "the concept of 'genre' to serve a key orienting function in both film production and film reception." 44 In cinematic representations of history, specific genre practices can be observed in the particular aesthetic and narrative configurations that typify costume dramas, ${ }^{45}$ historical epics, ${ }^{46}$ and biopics, as well as in nationally specific phenomena such as British heritage films. The concept of Historienfilm (widely used in the German-speaking world) is normally associated with these particular forms of cinematic representation of history, which necessarily narrows the concept's scope. My proposal of an expanded genre of historical film, by contrast, gives central place to the historical experiences created by film. This does not require consciously considered knowledge of, or extensive awareness of, the genre. Consequently, the historical film is a "silent" genre, which in both academic literature and popular discourse is only rarely articulated as such. ${ }^{47}$

One of the few attempts at a genre-based definition of historical films was undertaken by Robert Burgoyne, drawing on Rick Altman's semantic/syntactic/pragmatic approach. ${ }^{48}$ Central to Burgoyne's account is the idea that historical films are based on the principle of "reenactment": The imaginative reproduction of the past allows spectators to "relive" past events. ${ }^{49}$ "Reenactment" is the common feature that holds the historical 
film genre together across the whole spectrum of aesthetic and structural variations. ${ }^{50}$ Burgoyne's approach has some parallels with my concept of the histosphere as the core of the historical film genre. The concept of "reenactment" is likewise based on the idea of a simulated historical world constructed out of filmic figurations. However, the concept of the histosphere has a different theoretical foundation, which, as with my concept of genre, relies less on Altman than on certain fundamental phenomenological and philosophical premises. In the literature, the close connection between history and film genres is primarily considered from a philosophical perspective. According to Ricœur, we engage with the past through narrative, which in turn draws on a broad and variable repertoire of genres. ${ }^{51}$ Ricour compares history with narrative fiction and observes that "what is ultimately at stake in the case of the structural identity of the narrative function as well as in that of the truth claim of every narrative work, is the temporal character of human experience." 52 Historical and fictional narrations are based on the same "configurating operations" but differ in terms of their "truth claims." ${ }^{53}$ It is here, I suggest, that genre comes into play. Analogously to a (written) historical text, a historical film likewise makes a truth claim, based, firstly, on making the past present so as to produce meaning in the here-and-now, and, secondly, on the referential relation to history implemented by the mise-en-histoire. Although the precise arrangement is constantly changing in the context of diverging aesthetic and narrative strategies of representation, an aesthetic practice has been established at the heart of historical films that models historical worlds and makes them available to experience. As a genre, the historical film thus comprises a process that not only visually represents history but also refigures it as an experience of a spatially and temporally organized historical world.

Histospheres also utilize semantic processes to create historical experiences, with particular filmic signifiers forming the basis for microlevel communicative processes. Pierre Sorlin suggests that the criterion for membership of the historical film genre should be the use of signifiers that allow us to date the film's setting to a certain point in history. ${ }^{54}$ As well as characteristic semantic elements such as "the place and time the action is set, props and costumes, characters and their behavior," 55 iterative patterns of aesthetic design can also determine a film's "genreness." The faded colors in KU'DAMM 56, for instance, do not just refer to aged photographs; they are also a standard convention of historical films that has become established primarily thanks to blockbusters such as SAVING PRIVATE 
RYAN. The historical film genre is also typified by recurring auditory patterns and aesthetics that parallel these iterative strategies of visual design. ${ }^{56}$ Arranged in sound tableaus and soundscapes, noises and music play a key part in modeling a histosphere's historical worlds. For instance, the gently crunching footsteps of passersby mixed with soft violin music and the voice of a woman selling candy characterize the East German town in SKY WITHOUT STARS as a safe and homey place. As well as performing functions "that will apply across genres," such as creating a sense of an environment and its spatial qualities, focusing the spectator's attention on particular actions or events, giving information about characters' mental states, or conveying the atmosphere of a particular time, film sound can also perform tasks specific to a given genre..$^{57}$ An important role is played not just by similarities to historical audio documents but also by historical sounds modeled by media. Cinematic sound conventions are often preferred to faithful reproduction of actual sound. ${ }^{58}$ Sounds are sometimes even "imported" into historical films from other genres. A typical example of this is the gunshots at the start and end of SKY wITHOUT STARS, which are closer to the typical sound effects of 1950s Western films than the actual sound of gunfire. These amalgams of genres have the potential to increase our sense of familiarity with the historical world modeled by a film, helping to reduce the distance between the spectator and the historical past depicted on the screen. The arrangement and ordering of audiovisual elements in a histosphere reflect the syntactic level ${ }^{59}$ at which a sensuously available historical world is modeled and figured-one of the key hallmarks of the historical film genre.

The debates about genre discussed earlier concentrate mainly on the conventions, iconographies, plots, themes, and characters that define a genre. Against these sorts of primarily semiotic definitions, Barry Keith Grant raises the objection that it is virtually impossible to meaningfully categorize individual genre films without considering the specific type of experience we have of them..$^{60}$ The theory of the histosphere as the paradigmatic core of historical films, by contrast, is based on a phenomenological understanding of genre that explicitly includes the experience of the historical worlds constructed by film. While Grant speaks of the interdependence between film history and socio-historical processes at the time of the film's production, ${ }^{61} \mathrm{I}$ am more focused on spectators' living encounters with the films they watch. ${ }^{62}$ Historical films, as I have shown in this study, model audiovisual figurations that simulate a spatiotemporal structure in our perceptions that not only illusorily reconstructs historical 
spaces but makes these spaces sensuously available as a dynamic, historical lifeworld. ${ }^{63}$ Historical references serve to constitute a "perceptual realism" ${ }^{64}$ that also draws on the audience's mediatized experience of history. This process constructs a mise-en-histoire — an embedding of the film's historical world in a historical period-that allows us to connect the histospheres constructed by films to our conceptions of history. ${ }^{65}$ The resulting impression of an internally consistent, temporally arranged historical world goes hand in hand with a genre-specific, cinematic-historical experience of being-in-the-world-and-in-time. The design of historical films utilizes specific affective, situational, and reflective patterns. The perception of a histosphere encompasses aesthetically modeled moods and atmospheres that bring us as spectators physically and mentally closer to the action of the film. ${ }^{66}$ As elements of intense, immersive experiences, they help make the plot into a "temporarily focused matrix" ${ }^{\prime 67}$ of the spectator's perception. ${ }^{68}$ In combination with imaginative empathy with the characters, it is possible for the spectator to live the film's simulated historical world "from within." ${ }^{69}$ The resulting contiguity of historical world and subjective perception evokes a feeling of being able to physically touch the past. As per Frank R. Ankersmit's definition of historical experience, the historical film genre thus has the potential to give spectators the impression of making direct contact with past events and worlds. ${ }^{70}$

The historical experience this evokes results in part from complex processes of memory. As fundamental elements of histospheres, embodied memories play a key role in making it possible to experience the film's historical world as a physical reality, and add a bodily experiential dimension to the mise-en-histoire, which was initially understood solely as a reflective process. ${ }^{71}$ The historical film could accordingly also be understood as a type of body genre. ${ }^{72}$ Histospheres draw on two complementary forms of memory; a prereflective, bodily dimension that is activated while watching a film, and a reflective, historicizing dimension that retrospectively allows the film's historical world to be experienced as such. Histospheres are also actively involved in creating personal experiences with the potential to forge identity, in which personal and popular memories fuse together. ${ }^{73}$ I refer to the filmic figurations that connect a film's historical world to the spectator's memories as reminiscence triggers. ${ }^{74}$ The use of these triggers and the formation of prosthetic postmemory not only enable a concrete relationship to reality, but also transform aesthetic film experience into historical experience. ${ }^{75}$ The incorporative appropriation of filmic depictions of history prompted by synesthetic perception and 
embodied memories in turn enables a specific form of reflection. ${ }^{76}$ An inner "mirroring" of the historical worlds fills the empty space between the mise-en-histoire's historical references and the histosphere's model-like filmic figurations with self-reflexive experiences that lend the resulting conceptions of history a living, multilayered structure. This capacity to generate historical experiences through a complex interplay of audiovisual design and film experience is the distinctive feature that marks out historical films as a genre in their own right.

Like other genres, certain social functions can be attributed to historical films. For Francesco Casetti, genre films serve a storytelling function; they help "to give the audience new stories which will join the stories or the discourses which already circulate within the social space."77 Against the backdrop of the social apparatus provided by historical writing, historical films help determine which narratives enter popular historical consciousness and are given particular prominence. SKY WITHOUT STARS, for instance, attempts to establish the division of Germany as a central issue of the period. YEARS OF HUNGER explores the social implications of suffocating petit bourgeois life in the fledgling West Germany, while KU'DAMM 56 focuses on the oppression of women and the yearning for freedom expressed in the rock 'n' roll movement. At a political level, these films can be regarded as "cultural expressions" that not only have "social diagnostic

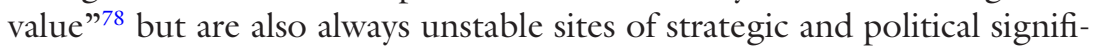
cance. ${ }^{79}$ How a historical film functions, what stories it tells, and the way in which it tells them thus also reveal something about the political circumstances and discourses at the time of its production. One common strategy for genre films to achieve contemporary relevance is to model crises and problems similar to those encountered by the spectators in their day-to-day lives. ${ }^{80}$ These sorts of connections to and models of contemporary issues can also be found in historical films, as part of the historical worlds they construct. Whether it be the dramatically failed attempt to form a border-spanning patchwork family in SKY WITHOUT STARS, the unbearably narrow-minded petit bourgeois mores in YEARS OF HUNGER, or the family torn apart by the war and its political consequences in KU'DAMM 56 , genre films often deal with paradigmatic forms of private, family, and social life and project them onto generic situations and events. This ability to connect to social issues is often combined with genre film's "bardic function": ${ }^{81}$ By repeatedly addressing painful conflicts and traumas, historical films help society to process the historical events and ruptures underlying them. For instance, while SKY WITHOUT STARS understands the 
division of Germany as a cruel imposition that tears families and lovers apart, in YEARS OF HUNGER and KU'DAMM 56 the largely unquestioned and repressed legacy of National Socialism is negotiated at the microlevel of familial ties and relationships. ${ }^{82}$ Kracauer regards this sort of modeling and mirroring as one of the main social functions of historical films. ${ }^{83}$ On this view, the historical film genre not only serves a "ritual function" 84 -nostalgically making the past present-but also actively shapes and steers ongoing social discourses.

The historical film genre is also interwoven with plurimedial iconographies and audiographies. On the basis of interactions between generic structures that cut across different media, it is possible to "observe and analyze complex (inter)medial and (inter)cultural processes of exchange." 85 For instance, Felix Zimmermann's study of historical experiences in recent video games proceeds from the phenomenological premise of sensuously available "historical atmospheres" (Vergangenheitsatmosphären) that extend bodily space to the space of virtual worlds ${ }^{86}$ Within the framework of game studies, Zimmermann is describing a very similar dimension of historical experience to that proposed for historical films by the theory of histospheres. As well as these transmedial connections between different theories, we can also consider specific plurimedial constellations at the level of representation. In KU'DAMM 56, for instance, the portrait of Elvis on the cover of the Spiegel magazine is both a historical reference and a point of connection to pop cultural image discourses (Fig. 8.1).

As a news magazine, the Spiegel, for all its striving for topicality and currentness, also uses strategies of historicizing storytelling, sometimes deploying similar generic structures to historical films. Moreover, in the wake of the Spiegel affair, ${ }^{87}$ the magazine was long regarded as a subversive publication, and this reputation is used in retrospective films like KU'DAMM 56 to reinforce the rebellious image of certain characters. The use of plurimedial codes relating to "contemporary history and social classifications" encompasses not just the visual level but also the soundtrack. ${ }^{88}$ The rock 'n' roll music in KU'DAMM 56 points far beyond purely cinematic associations. Bill Haley's global hit "Rock Around the Clock," which Freddy's band plays at the wedding of Monika's sister Helga, is presented as synonymous with the young rock 'n' roll fans' attitude to life. The song marked an important milestone in the plurimedial marketing of pop music, which explicitly also includes film. After "Rock Around the Clock" helped BLACKBOARD JUNGLE (1955; dir. Richard Brooks), a drama centered on the younger generation, to great success, a Hollywood film based around 


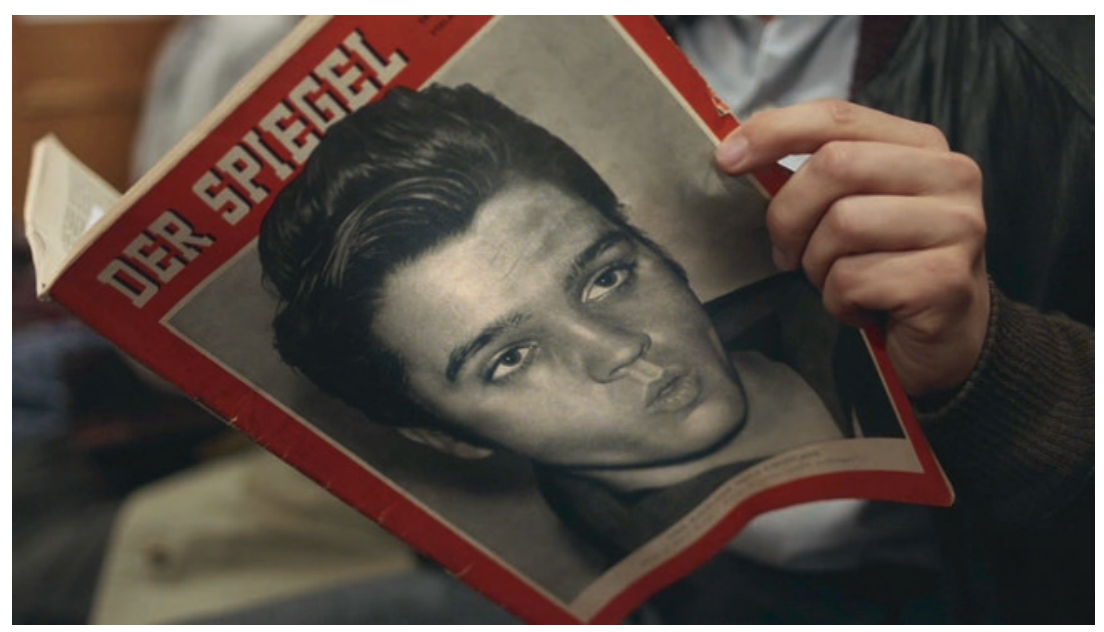

Fig. 8.1 Plurimedial constellations: Elvis on the cover of Spiegel in KU'DAmм 56

Haley's hit was rushed into production. ROCK AROUND THE CLOCK (1956; dir. Fred F. Sears) played a pivotal role in the worldwide breakthrough of rock 'n' roll as a pop cultural phenomenon. Intermedial references like the Spiegel cover and Haley's hit thus not only expand histospheres to include cultural and social discourses, but also embed them in a "complex social network," 89 thereby marking out historical films as not just a genre but part of a plurimedial constellation capable of forming and constituting history. According to sociologist Manuel Castells, in today's "network society" geographical proximity matters less than relational proximity, ${ }^{90}$ which genres help to produce. The way in which the dominant processes and functions in plurimedial networks are organized also significantly contributes to the dissemination of films. A historical film's potential influence will be realized "to the extent that the film is plurimedially disseminatedorally, textually, or visually." ${ }^{11}$ Sabine Moller infers from this that the significance and reach of a film rise in proportion to the quality of the networks in which it is embedded, and so also the probability that it will "shape collective processes of memory." "Plurimedial networks thus not only play a key role in the dissemination and appropriation of individual historical films, but also contribute to the refiguration of historical consciousness. 


\section{CONCLUSION}

In this chapter, I have developed a model of incorporative appropriation of history, building on theories of the phenomenological relationship between the spectator's body and the world. I concluded that the process of appropriation also inscribes the aesthetic parameters of a cinematichistorical way of thinking into our historical consciousness. This shapes a specific historical film experience, which then in turn serves as the paradigmatic core of my proposed concept of a historical film genre.

The theories of mise-en-histoire, imaginative empathy, and prosthetic postmemory set out in the preceding chapters showed that the appropriation of historical films gives rise to a new, specifically filmic concept of history. A histosphere's simulated historical world occupies the role of an external sphere that in the process of reception becomes part of our own inner sphere. We are able to physically experience the materiality of the simulated historical world by sensuously incorporating the underlying audiovisual figurations, thereby opening up new horizons of understanding. Individual experience blends with collective conceptions of history, making historical memory into a portable and nonessentialist good that blurs the boundaries between personal and collective memory. ${ }^{93}$ The incorporative appropriation of filmically constructed representations of history develops an incredible power, capable of affirming, overriding, or calling into question existing ideas of history.

The preceding chapters showed that an aesthetic practice has been established at the heart of historical films that models historical worlds and makes them available to experience. Following on from this, the second section of this chapter sketched an account of the historical film genre in which histospheres serve as the constitutive core. As a genre, I argued, the historical film comprises a communicative process that not only visually represents history but also refigures it as an experience of a spatially and temporally organized historical world. This results in an intense feeling of being-in-the-world-and-in-time. Mise-en-histoire in turn allows filmically constructed histospheres to be combined with our existing conceptions of history, referring to extra-filmic configurations of knowledge in a way that makes them immediately present to the spectator. As per Frank R. Ankersmit's definition of historical experience, the historical film genre can thus give spectators the impression of making direct contact with the past. ${ }^{94}$ Incorporating conventions of other genres into the construction of histospheres increases our familiarity with the filmically modeled historical 
worlds. The historical film genre is also interwoven with plurimedial iconographies and audiographies, giving rise to generic structures that cut across different media. On the basis of its communicative practice, the genre can be assigned certain social functions: First, historical films help determine which narratives enter popular historical consciousness and are given particular prominence. Second, by addressing painful conflicts and traumas, historical films help society to process the historical events and ruptures underlying them. Historical films thus actively shape the development of contemporary ideas and discourses of history. In combination with histospheres' unique potential to make the depicted historical worlds physically experienceable, this gives the genre considerable power and influence.

\section{Notes}

1. Andreas Hepp, "Kommunikative Aneignung," in Lothar Mikos and Claudia Wegener (eds.), Qualitative Medienforschung: Ein Handbuch, Konstanz 2005, p. 68.

2. Ibid.

3. Cf. Kappelhoff's concept of the "poiesis of cinematic seeing"; Hermann Kappelhoff, Kognition und Reflexion: Zur Theorie filmischen Denkens, Berlin 2018, p. 10.

4. Detlev Schöttker, Konstruktiver Fragmentarismus: Form und Rezeption der Schriften Walter Benjamins, Stuttgart 1999, p. 244.

5. As Gertrud Koch writes, "Die Einstellung ist die Einstellung": a phrase that literally means the "shot is the shot," but also plays on the ambiguity of the German Einstellung, which can refer both to a positioning or framing of something, and an attitude or stance toward it. Gertrud Koch, Die Einstellung ist die Einstellung: Visuelle Konstruktionen des Judentums, Frankfurt 1992, p. 9.

6. Friedrich Krotz speaks of a "mediatization of the everyday," which he describes as a wide-reaching social process. See Friedrich Krotz, Die Mediatisierung kommunikativen Handelns: Der Wandel von Alltag und sozialen Beziehungen, Kultur und Gesellschaft durch die Medien, Wiesbaden 2001, p. 33.

7. Vivian Sobchack, "The Scene of the Screen: Envisioning Photographic, Cinematic, and Electronic 'Presence," 2016, https://reframe.sussex. ac.uk/post-cinema/2-1-sobchack/ (last accessed May 1, 2020).

8. Luke Tredinnick, "The Making of History: Remediating Historicized Experience," in Toni Weller (ed.), History in the Digital Age, London and New York 2013, p. 41. 
9. Ibid., p. 56.

10. Ibid., p. 56.

11. Jean Baudrillard, Simulacra and Simulation, Ann Arbor 1994, pp. 46-47.

12. Alison Landsberg, Prosthetic Memory: The Transformation of American Remembrance in the Age of Mass Culture, New York 2004.

13. Baudrillard (1994, p. 46).

14. Since our postmemory, activated by film perception, is no longer based on intergenerational transmission of our parents or grandparents' actual biographical experiences, but on experiences created by media-that is to say, on prosthetic memory - there is a convergence of embodied memories and historical referentialization. See also the section "Prosthetic postmemory" in the previous chapter.

15. Bernhard Groß, "The Relationship between Film and History in Early German Postwar Cinema," 2018, https://film-history.org/issues/text/ relationship-between-film-and-history-early-german-postwar-cinema (last accessed May 1, 2020).

16. Ibid.

17. Ibid.

18. By this, Benjamin means photographic devices and operations such as "lenses" and "enlargements," which he says disclose the "optical unconscious" just as psychoanalysis does the "instinctual unconscious." Walter Benjamin, “A Short History of Photography," Screen 13:1, 1972, p. 7.

19. Kracauer's "redemption of physical reality" is based on this specifically filmic way of structuring and perceiving the world. Siegfried Kracauer, Theory of Film: The Redemption of Physical Reality, Princeton 1997.

20. Heike Klippel, Gedächtnis und Kino, Basel 1997, p. 188.

21. Ibid.

22. According to Thomas Elsaesser, "where once it was something one read about, one drew lessons from or tried to leave behind, inspected through stone monuments, written documents and other signs," history now "appears to exist in suspended animation, neither exactly 'behind' us, nor part of our present." Thomas Elsaesser, "One train may be hiding another': private history, memory and national identity," 1999, http:// www.screeningthepast.com/2014/12/one-train-may-be-hiding-anotherprivate-history-memory-and-national-identity/ (last accessed May 1, 2020).

23. Alphonso Lingis, "Bodies that Touch Us," Thesis Eleven 36:1, 1993, pp. 159-167.

24. Lingis gives the example of a situation in which we are standing facing a friend, and argues that we conceive analogously of perspectives such as that of a sequoia looking down at us. Ibid., p. 162.

25. Ibid. 
26. Walter Benjamin, "The Work of Art in the Age of Mechanical Reproduction," in his Illuminations, New York 2007, p. 239.

27. Kracauer (1997, p. 297).

28. Landsberg (2004, pp. 18-19).

29. Kracauer (1997, p. 305).

30. Thomas Morsch, Medienästhetik des Films: Verkörperte Wabrnebmung und ästhetische Erfahrung im Kino, Munich and Paderborn 2011, p. 15.

31. Ibid.

32. Kracauer (1997, p. 305).

33. Here I am following Jörn Rüsen, who formulates matters more generally: "Through interpretation, historical experience becomes historical knowledge." Jörn Rüsen, Historik: Theorie der Geschichtswissenschaft, Cologne 2013, p. 41.

34. Ibid., p. 38.

35. In modern societies, this means integrating the perception of difference between times into a "historical idea of change [...] already conceived of as meaningful." This historical orientation also extends to people and their inner lives, "for 'world' of course also refers to the human beings living in that world and producing meaning through their engagement with it." Ibid., pp. 40-41.

36. See on this point the sections "Immersive experiences" and "Imaginative empathy" in the chapter "Immersion and empathy" and the section "Reminiscence triggers" in the previous chapter.

37. Paul Ricœur, Time and Narrative, vol. 1, Chicago and London 1984 (hereinafter Ricœur 1984), pp. 64ff.

38. Ivo Ritzer and Peter W. Schulze (eds.), Transmediale Genre-Passagen: Interdisziplinäre Perspektiven, Wiesbaden 2016, pp. 1-2.

39. Peter Scheinpflug, Genre-Theorie: Eine Einführung, Berlin 2014, p. 8.

40. Francesco Casetti, Communicative Negotiation in Cinema and Television, Milan 2002, p. 31.

41. Angela Keppler and Martin Seel, "Über den Status filmischer Genres," montage AV 11:2, 2002, p. 65.

42. David Bordwell, Making Meaning: Inference and Rhetoric in the Interpretation of Cinema, Cambridge 1989, pp. 147-148.

43. Ritzer and Schulze (2016, p. 8).

44. Jörg Schweinitz, "'Genre' und lebendiges Genrebewusstsein: Geschichte eines Begriffs und Probleme seiner Konzeptualisierung in der Filmwissenschaft," montage AV 3:2, 1994, p. 113.

45. Fabienne Liptay and Matthias Bauer (eds.), Historien- und Kostümfilm, Stuttgart 2013.

46. On the specific aesthetic form of the historical epic, see Vivian Sobchack, “'Surge and Splendor': A Phenomenology of the Hollywood Historical 
Epic," in Barry Keith Grant (ed.), Film Genre Reader III, Austin 2007, pp. 296-323.

47. In Handbuch Filmgenre, for instance, the standard German reference work on film, there is not (yet) a chapter on historical films. Marcus Stiglegger (ed.), Handbuch Filmgenre, Wiesbaden 2018, https://link.springer.com/ referencework/10.1007/978-3-658-09631-1 (last accessed May 1, 2020).

48. Robert Burgoyne, The Hollywood Historical Film, Malden, MA, 2008, p. 7. On Rick Altman's theory of genre, see Rick Altman, Film/Genre, London 1999.

49. Burgoyne (2008, p. 7).

50. Burgoyne specifically mentions the epic, the biopic, the war film, and the topical film. Ibid., pp. 8-9.

51. Ricœur (1984).

52. Ibid., p. 3.

53. Paul Ricœur, Time and Narrative, vol. 2, Chicago and London 1984, p. 3.

54. Pierre Sorlin, The Film in History: Restaging the Past, Oxford 1980, p. 20. Sorlin's view is broadly compatible with Altman's semantic/syntactic/ pragmatic approach. See Altman (1999).

55. Malte Hagener, "Der Begriff Genre," in Rainer Rother and Hans C. Blumenberg (eds.), Die Lust am Genre: Verbrechergeschichten aus Deutschland, Berlin 2011, p. 16.

56. Rasmus Greiner, "Filmton, Geschichte und Genretheorie," in Ivo Ritzer and Peter W. Schulze (eds.), Transmediale Genre-Passagen: Interdisziplinäre Perspektiven, Wiesbaden 2016, p. 185.

57. Birger Langkjær, "Making Fictions Sound Real - On Film Sound, Perceptual Realism and Genre," MedieKultur 26:48, 2010, pp. 13-14.

58. See Greiner (2016, p. 185).

59. Hagener (2011, p. 16).

60. Barry Keith Grant, Film Genre: From Iconography to Ideology, London 2007 , p. 116.

61. Grant is primarily referring to the youth protests in the period around 1968, when the film he is analyzing, BONNIE AND CLYDE (1967; dir. Arthur Penn), was made.

62. This experience is, in turn, closely related to processes of genre formation and differentiation. See Ritzer and Schulze (2016, p. 8).

63. See the chapter "Modeling and perceiving" in the present volume.

64. Stephen Prince, "True Lies: Perceptual Realism, Digital Images, and Film Theory," Film Quarterly 49:3, 1996, p. 32.

65. See the section "From mise-en-scène to mise-en-histoire" in the chapter "Modeling and perceiving."

66. See the section "Mood and atmosphere" in the chapter "Immersion and empathy."

67. Christiane Voss, "Fiktionale Immersion," montage AV 17:2, 2008, p. 82. 
68. See the section "Immersive experiences" in the chapter "Immersion and empathy."

69. See the section "Imaginative empathy" in the chapter "Immersion and empathy."

70. Frank R. Ankersmit, Die historische Erfahrung, Berlin 2012, p. 56.

71. See the section "Film/body/memory" in the chapter "Experience and remembering."

72. Unlike in Linda Williams's examples of porn films, horror films, and melodramas, however, this body genre is not articulated through the manifestation of certain fantasies on the female body, but rather through an initially genderless incarnation that occurs in the integration of subjective embodied memories into film perception. See Linda Williams, "Film Bodies: Gender, Genre, and Excess," Film Quarterly 44:4, 1991, pp. 2-13.

73. These experiences are likewise addressed as memories by film.

74. See the section of the same name in the previous chapter.

75. See the section "Prosthetic postmemory" in the previous chapter.

76. See the section "Incorporative appropriation" in this chapter.

77. Casetti $(2002$, p. 30$)$.

78. Morsch $(2011$, p. 11$)$.

79. See Hagener (2011, p. 14).

80. See Casetti (2002, pp. 30-31).

81. On this point, Casetti writes: "[Genre film] helps to deal with some issues concerning a community, re-proposing them to the public attention with each story (bardic function).” Ibid., p. 31.

82. In YEARS OF HUNGER, the young protagonist Ursula is critical of the repression of Nazi-era crimes and, relatedly, of current events like the remilitarization of West Germany and the Communist Party ban. She encounters resistance as a result, especially at school. Her left-wing father increasingly succumbs to social pressure. In KU'DAMM 56, Monika (likewise a member of the younger generation) learns that her mother's dance school only came into her family's possession after it was seized from its Jewish owners by the Nazis. Because of this crime, Monika's father does not return. Instead, he creates a new socialist identity for himself in the East, and also starts a new family there.

83. Kracauer refers here to Greek mythology, in which Perseus uses the shield of Athena as a mirror in order to battle Medusa without looking at her directly, so as to avoid being turned to stone. Kracauer understands the film image as an analogous tool that makes it possible to address horrors such as the Holocaust. See Kracauer (1997, pp. 305-306).

84. Casetti (2002, p. 31 ).

85. Ritzer and Schulze (2016, p. 2).

86. Felix Zimmermann, "Digitale Spiele als historische Erlebnisräume: Ein Zugang zu Vergangenheitsatmosphären im Explorative Game,” master's 
thesis, University of Cologne 2018, https://kups.ub.uni-koeln.de/8286/ (last accessed May 1, 2020).

87. On the Spiegel affair, see Horst Pöttker, "Meilenstein der Pressefreiheit 50 Jahre Spiegel-Affäre," Aus Politik und Zeitgeschichte (APuZ 29-31/2012), July 10, 2012.

88. Christoph Metzger, "Genre und kulturelle Codes im Film," in Josef Kloppenburg (ed.), Das Handbuch der Filmmusik: Geschichte - Ästhetik Funktionalität, Laaber 2012, pp. 447-448.

89. Astrid Erll and Stephanie Wodianka (eds.), Film und kulturelle Erinnerung: Plurimediale Konstellationen, Berlin 2008, p. 7.

90. Manuel Castells, The Rise of the Network Society, vol. 1 of The Information Age: Economy, Society and Culture, Oxford 2000.

91. Sabine Moller, Zeitgeschichte sehen: Die Aneignung von Vergangenheit durch Filme und ibre Zuschaner, Berlin 2018, p. 42.

92. Ibid.

93. Landsberg (2004, pp. 18-19).

94. Ankersmit (2012, p. 56).

\section{BIBLIOGRAPHY}

Rick Altman, Film/Genre, London 1999.

Frank R. Ankersmit, Die historische Erfahrung, Berlin 2012.

Jean Baudrillard, Simulacra and Simulation, Ann Arbor 1994.

Walter Benjamin, "The Work of Art in the Age of Mechanical Reproduction," in his Illuminations, New York 2007, pp. 211-244.

Walter Benjamin, "A Short History of Photography," Screen 13:1, 1972, pp. 5-26.

David Bordwell, Making Meaning: Inference and Rhetoric in the Interpretation of Cinema, Cambridge 1989.

Robert Burgoyne, The Hollywood Historical Film, Malden, MA, 2008.

Francesco Casetti, Communicative Negotiation in Cinema and Television, Milan 2002.

Manuel Castells, The Rise of the Network Society, vol. 1 of The Information Age: Economy, Society and Culture, Oxford 2000.

Thomas Elsaesser, “'One train may be hiding another': private history, memory and national identity," 1999, http://www.screeningthepast.com/2014/12/ one-train-may-be-hiding-another-private-history-memory-and-national-identity/ (last accessed May 1, 2020).

Astrid Erll and Stephanie Wodianka (eds.), Film und kulturelle Erinnerung: Plurimediale Konstellationen, Berlin 2008.

Barry Keith Grant, Film Genre: From Iconography to Ideology, London 2007.

Rasmus Greiner, "Filmton, Geschichte und Genretheorie," in Ritzer and Schulze 2016, pp. 183-194. 
Bernhard Groß, "The Relationship between Film and History in Early German Postwar Cinema," 2018, https://film-history.org/issues/text/relationshipbetween-film-and-history-early-german-postwar-cinema (last accessed May 1, 2020).

Malte Hagener, "Der Begriff Genre," in Rainer Rother and Hans C. Blumenberg (eds.), Die Lust am Genre: Verbrechergeschichten aus Deutschland, Berlin 2011, pp. 11-22.

Andreas Hepp, "Kommunikative Aneignung," in Lothar Mikos and Claudia Wegener (eds.), Qualitative Medienforschung: Ein Handbuch, Konstanz 2005, pp. 67-79.

Hermann Kappelhoff, Kognition und Reflexion: Zur Theorie filmischen Denkens, Berlin 2018.

Angela Keppler and Martin Seel, "Über den Status filmischer Genres," montage AV 11:2, 2002, pp. 58-68.

Gertrud Koch, Die Einstellung ist die Einstellung: Visuelle Konstruktionen des Judentums, Frankfurt 1992.

Heike Klippel, Gedächtnis und Kino, Basel 1997.

Siegfried Kracauer, Theory of Film: The Redemption of Physical Reality, Princeton 1997.

Friedrich Krotz, Die Mediatisierung kommunikativen Handelns: Der Wandel von Alltag und sozialen Beziehungen, Kultur und Gesellschaft durch die Medien, Wiesbaden 2001.

Alison Landsberg, Prosthetic Memory: The Transformation of American Remembrance in the Age of Mass Culture, New York 2004.

Birger Langkjær, "Making Fictions Sound Real-On Film Sound, Perceptual Realism and Genre," MedieKultur 26:48, 2010, pp. 5-17.

Alphonso Lingis, "Bodies that Touch Us," Thesis Eleven 36:1, 1993, pp. 159-167.

Fabienne Liptay and Matthias Bauer (eds.), Historien- und Kostümfilm, Stuttgart 2013.

Christoph Metzger, "Genre und kulturelle Codes im Film," in Josef Kloppenburg (ed.), Das Handbuch der Filmmusik: Geschichte - Ästhetik - Funktionalität, Laaber 2012, pp. 413-450.

Sabine Moller, Zeitgeschichte sehen: Die Aneignung von Vergangenheit durch Filme und ibre Zuschauer, Berlin 2018.

Thomas Morsch, Medienästhetik des Films: Verkörperte Wabrnehmung und ästhetische Erfahrung im Kino, Munich and Paderborn 2011.

Horst Pöttker, "Meilenstein der Pressefreiheit - 50 Jahre Spiegel-Affäre," Aus Politik und Zeitgeschichte (APuZ 29-31/2012), July 10, 2012.

Stephen Prince, “True Lies: Perceptual Realism, Digital Images, and Film Theory," Film Quarterly 49:3, 1996, pp. 27-37.

Paul Ricour, Time and Narrative, vol. 2, Chicago and London 1984.

Paul Ricour, Time and Narrative, vol. 1, Chicago and London 1984. 
Ivo Ritzer and Peter W. Schulze (eds.), Transmediale Genre-Passagen: Interdisziplinäre Perspektiven, Wiesbaden 2016.

Jörn Rüsen, Historik: Theorie der Geschichtswissenschaft, Cologne 2013.

Peter Scheinpflug, Genre-Theorie: Eine Einführung, Berlin 2014.

Detlev Schöttker, Konstruktiver Fragmentarismus: Form und Rezeption der Schriften Walter Benjamins, Stuttgart 1999.

Jörg Schweinitz, “'Genre' und lebendiges Genrebewusstsein: Geschichte eines Begriffs und Probleme seiner Konzeptualisierung in der Filmwissenschaft," montage AV 3:2, 1994, pp. 99-118.

Vivian Sobchack, "The Scene of the Screen: Envisioning Photographic, Cinematic, and Electronic 'Presence,"” 2016, https://reframe.sussex.ac.uk/postcinema/2-1-sobchack/ (last accessed May 1, 2020).

Vivian Sobchack, "'Surge and Splendor': A Phenomenology of the Hollywood Historical Epic," in Barry Keith Grant (ed.), Film Genre Reader III, Austin 2007, pp. 296-323.

Pierre Sorlin, The Film in History: Restaging the Past, Oxford 1980.

Marcus Stiglegger (ed.), Handbuch Filmgenre, Wiesbaden 2018, https://link. springer.com/referencework/10.1007/978-3-658-09631-1 (last accessed May 1, 2020).

Luke Tredinnick, "The Making of History: Remediating Historicized Experience," in Toni Weller (ed.), History in the Digital Age, London and New York 2013, pp. 39-60.

Christiane Voss, "Fiktionale Immersion," montage AV 17:2, 2008, pp. 69-86.

Linda Williams, "Film Bodies: Gender, Genre, and Excess," Film Quarterly 44:4, 1991, pp. 2-13.

Felix Zimmermann, "Digitale Spiele als historische Erlebnisräume: Ein Zugang zu Vergangenheitsatmosphären im Explorative Game," master's thesis, University of Cologne 2018, https://kups.ub.uni-koeln.de/8286/ (last accessed May 1, 2020).

\section{FiLMOGRAPHY}

Blackboard Jungle; dir. Richard Brooks; USA 1955.

Bonnie and Clyde; dir. Arthur Penn; USA 1967.

Ku'damm 56; dir. Sven Bohse; Germany 2016.

Rock Around the Clock; dir. Fred F. Sears; USA 1956.

Sky without Stars (Himmel ohne Sterne); dir. Helmut Käutner; Federal Republic of Germany 1955.

Years of Hunger (Hungerjahre); dir. Jutta Brückner; Federal Republic of Germany 1980. 
Open Access This chapter is licensed under the terms of the Creative Commons Attribution 4.0 International License (http://creativecommons.org/licenses/ by $/ 4.0 /)$, which permits use, sharing, adaptation, distribution and reproduction in any medium or format, as long as you give appropriate credit to the original author(s) and the source, provide a link to the Creative Commons licence and indicate if changes were made.

The images or other third party material in this chapter are included in the chapter's Creative Commons licence, unless indicated otherwise in a credit line to the material. If material is not included in the chapter's Creative Commons licence and your intended use is not permitted by statutory regulation or exceeds the permitted use, you will need to obtain permission directly from the copyright holder. 